\title{
O IDEÁRIO DA GUERRA FRIA NAS IMAGENS DA RADIODIFUSÃO INTERNACIONAL
}

\author{
Antonio Argolo Silva Neto ${ }^{1}$ \\ Edson Dias Ferreira ${ }^{2}$ \\ Flávio Aurélio Braggion Archangelo ${ }^{3}$
}

Resumo: Este trabalho abrange o recorte da pesquisa de mestrado, sob o título de "Radiodifusão Internacional: o desenho do mundo na sintonia das Ondas Curtas" pelo Programa de Pós-Graduação em Desenho, Cultura e Interatividade (PPGDCI) da Universidade Estadual de Feira de Santana (UEFS). Procuro analisar a imagens produzidas durante a Guerra Fria a partir das propostas de comunicação das rádios internacionais, que transmitem programas em língua portuguesa e espanhola para o Brasil na faixa das Ondas Curtas (OC). Objetivos: identificar as formas de difusão de imagens da radiodifusão para o exterior; investigar as imagens que são veiculadas através da dimensão sonora e visual; analisar a conjuntura política e cultural do mundo a partir das imagens captadas pelo viés radiográfico. Trata-se de uma pesquisa semiótica baseada pela análise iconográfica, a partir da investigação dos programas e cartões QSL (materiais radiográficos) acostados ao acervo do pesquisador. Os resultados indicam que as imagens radiográficas fazem parte das informações difundidas na programação e se constituem num importante instrumento de propaganda política e mediação cultural. Elas possibilitam a reflexão de fatos históricos, e, por sua vez, circunscritos no imaginário coletivo, contribuindo para dar visibilidade aos diferentes pensamentos, veiculados nos microfones das rádios internacionais no ápice da Guerra Fria.

Palavras-Chave: Comunicação, Cultura, Imagem.

Abstract: This research is a part of the master research, when I discussed about "international broadcasting: the world's draw in the shortwave dial" by the Feira de Santana State University (UEFS). My aim is to analyze the images produced during the Cold War from this international radios communication's purpose, which broadcast programs in Portuguese and Spanish to Brazil in shortwave. Goals: identify the ways of image diffusion in the broadcasting to the foreign; investigate the images which are linked through the

1 Pedagogo e Especialista em Antropologia com Ênfase em Cultura Afro-Brasileira pela Universidade Estadual do Sudoeste da Bahia (UESB); Mestre em Desenho, Cultura e Interatividade, pela Universidade Estadual de Feira de Santana (UEFS). Endereço eletrônico: dxargolo@yahoo.com.br. Sítio de internet: www.radiografiadx.blogspot.com.

Professor PhD em Ciências Sociais, Antropologia; Docente do Programa de PósGraduação em Desenho, Cultura e Interatividade (PPGDCI/UEFS). Endereço eletrônico: edsonposuesb@yahoo.com.br. - Orientador.

Professor Doutor em Comunicação Social pela Universidade Metodista de São Paulo (UMESP). Endereço eletrônico: flavio.archangelo@gmail.com. - Orientador. 
visual and full sound dimension; analyze the world's political and cultural conjecture from the captured images by the bias radiographic. It is a semiotic research based by the iconography analyses, from the investigation of the programs and QSLs card (radiographic materials) accosted the collection of the researcher. The results indicate the radiographic images are part of the information disseminated in the programming and they constitute an important instrument of political propaganda and cultural mediation. They enable the reflection of historic events, and, in turn, limited the collective imagination. Contributing to give visibility to the different thoughts conveyed in the international radio microphones at the height of the Cold War.

Keywords: Communication, Culture, Imaginary.

\section{INTRODUÇÃO}

A radiodifusão é um fenômeno recente na história mundial. Ela começa a ganhar notoriedade no início do século $\mathrm{XX}$, em meio à crise na comunicação gráfica, principalmente pela facilidade que a mídia eletroeletrônica dispõe em alcançar grande quantidade de pessoas de níveis culturais e diferentes espaços geográficos.

Entretanto, a princípio, o rádio ainda se limitava às transmissões em Código Morse e servia como aparato de uso restrito às forças políticomilitares. Já transmitindo a voz humana, por volta de 1921 se apropria de uma interface de transmissão conhecida como Ondas Curtas $^{4}$ (OC) e alcança grandes distâncias. Portanto, tornando-se uma importante tecnologia para atender à demanda de comunicação naquela época. $E$, ainda hoje continua presente como mídia alternativa em boa parte dos receptores convencionais.

Nessa conjuntura, a radiodifusão via OC começa a se projetar nos períodos compreendidos entre a I e II Guerra Mundial. Esses conflitos contribuíram para uma nova modalidade radiofônica, denominada de "serviços internacionais" ${ }^{5}$. Tais serviços (programas) começam a ser irradiados de vários países, dirigidos aos cidadãos de outros países, em dezenas de lín-

4 As Ondas Curtas referem-se à parte do espectro eletromagnético, que corresponde às frequências compreendidas entre 3 e $30 \mathrm{MHz}$. Naturalmente, uma opção de sintonia que vai além das faixas de AM e FM, disponíveis nos receptores convencionais. Sua principal característica é a propagação a longas distâncias, tornando possíveis comunicações tais como emissões radiofônicas internacionais, nacionais, radioamadorismo e estações móveis marítimas.

5 Entende-se por serviços internacionais as transmissões radiofônicas, em vários idiomas, destinadas para uma audiência externa, isto é, para pessoas de outras partes do mundo.

158 Número temático: Desenho e Educação: Cultura Visual e Cidade. A Cor das Letras - UEFS, n. 
guas e centenas de horas diárias - incluindo programas de várias partes do globo em língua portuguesa para o Brasil.

É nesse escopo ideológico que proponho discutir as imagens do mundo difundidas pelo rádio. Para isso, me valho do material da pesquisa e das experiências na sintonia internacional. Comecei a sintonizar, escrever e receber materiais dessas emissoras por volta de 1988. A partir dessas fontes coletadas ao longo dos anos procurei inserir o rádio nas minhas pesquisas. Chegando ao Mestrado, senti a necessidade de adentrar à investigação das imagens visuais e sonoras proporcionada pelo rádio, assim como nas suas relações de sentido com a audiência brasileira.

Nesse artigo, procuro analisar sob o olhar semiótico e iconográfico as mensagens produzidas na esfera radiofônica em sua perspectiva sonora e visual. Sendo que as imagens visuais são cartões de verificação de sintonia, produzidos graficamente pelas próprias emissoras para confirmar a recepção dos ouvintes e difundir aspectos culturais, turísticos e ideológicos dos respectivos países de transmissão.

\section{A INTERFACE VISUAL GRÁFICA DA SINTONIA ESTRANGEIRA}

A mídia eletroeletrônica delegou aos mass media uma função importante na difusão das imagens no mundo contemporãneo, pois participa efetivamente das trocas culturais, que se repercutem na forma de viver em sociedade. Entretanto, houve um tempo em que o rádio era o único meio de se ter acesso às informações instantâneas. Para saber o que se passava em outras partes do mundo era preciso recorrer ao receptor de OC e manter-se em silêncio, pois o ato de ouvir rádio se tratava de uma prática ainda proibida pelas autoridades.

Foi no âmbito da Guerra Fria que o rádio experimentou sua massificação. $O$ mundo estava dividido pelas superpotências e havia não apenas o interesse pela hegemonia política entre comunismo $\mathrm{x}$ capitalismo, mas também o desejo da comunidade mundial em difundir os valores humanos e construir uma cultura de paz. Assim, surgiram as "rádios internacionais", transmitindo em dezenas de línguas e dialetos para uma audiência localizada em países distantes, incluindo o Brasil.

Para a Enciclopédia Mirador (1990) esses programas servem para difundir modos de vida e contrapor visões de mundo. Já o Serviço Brasileiro da BBC (1998) destaca o papel político das suas emissões radiofônicas como interlocutoras da população brasileira, na época silenciada pela Ditadura Militar. No âmbito da Guerra Fria: "[...] Margareth Thatcher, declarou, certa 
vez, que os programas de rádio para o exterior contribuíram mais para a transformação liberal do mundo do que os batalhões armados [...]" (RADIO DEUTSCHE WELLE, 1992, p. 1).

Ao situar o rádio como propulsor de imagens, logo vem à mente algumas indagações: afinal, de que forma a mídia sonora pode transmitir imagens? Qual o vínculo do rádio com as representações mentais e visuais, na concepção das imagens dos países de emissão, pelos sujeitos da audiência? Quais são as imagens sonoro/visuais que é possível identificar na iconografia radiográfica?

À luz da semiótica, Joly (1996) situa a imagem como a representação de algo que está ausente e pode ser perceptivel tanto nas suas formas visuais, fenômenos naturais, quanto nas imagens mentais dos pensamentos, sonhos, poesias, narrações, devaneios... Portanto, a imagem ganha sentido porque perpassa pela faculdade da psique e pode ser apropriada pelos humanos como instrumento de comunicação e representação visual.

Para McLuhan (1964), diferente da televisão, o rádio se constitui numa linguagem desprovida de imagens visuais. Contudo, sua visualidade torna-se latente mediante as interações humanas, pela condição de "ser imaginativo", sensível à construção dos sentidos ao interagir com as mensagens do rádio. Por isso, Bachelard (1985) teoriza que o uso do rádio veio suprir não apenas a necessidade de informação e mediação na sociedade, mas também a intensidade mental, tão necessária no mundo contemporâneo.

Em se tratando das imagens visuais - que nos interessa nessa investigação - a radiodifusão internacional também favoreceu a circulação de imagens gráficas associadas à programação. Esse material visa premiar o contato de sua audiência e divulgar pontos de vistas ideológicos e culturais dos respectivos países de emissão. Essa é a ideia básica do "cartão QSL", um instrumento visual que tem sido utilizado até os dias de hoje.

De acordo com Azevedo (2004, p. 9): “[...] QSL faz parte do Código Fonético Internacional, que foi aprovado [...] em Genebra a 21 de dezembro de 1959". QSL, portanto, é a combinação de três letras iniciada pelo "Q" utilizado na comunicação telegráfica - , significa "acuso de recebimento" e pode assumir as condições interrogativas ou afirmativas. Basicamente, trata-se de um "cartão gráfico" que é produzido por uma determinada rádio para confirmar a sintonia dos ouvintes e ao mesmo tempo empreender a propaganda cultural e ideológica da emissora ou do país. 
Figuras 1 e 2 - QSL da Rádio Internacional da China (frente e verso)
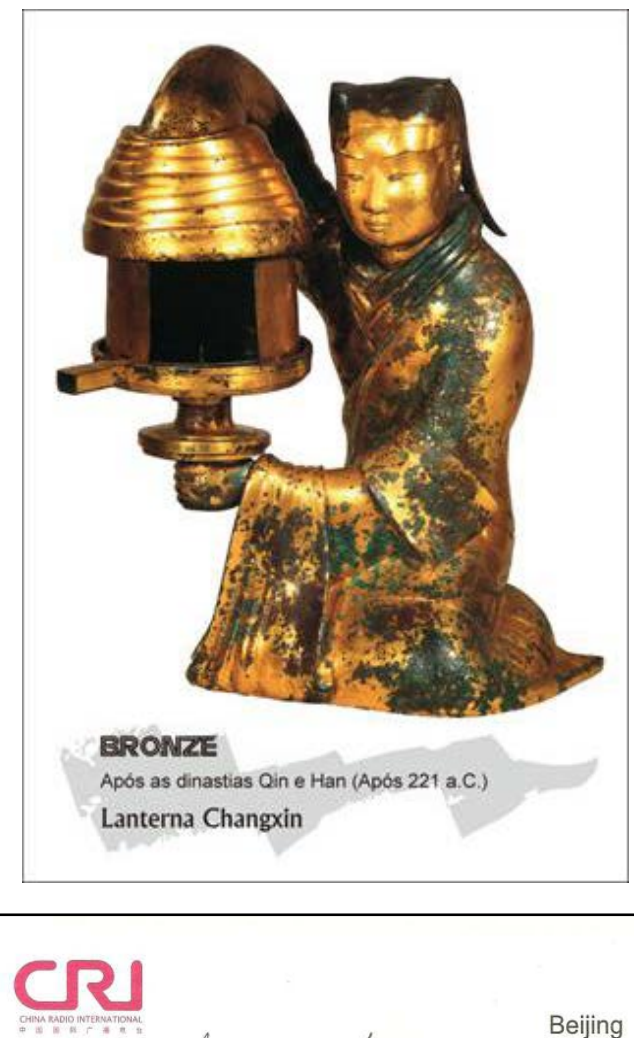

Prezado amigo, Hontomio Argolo

Beijing

Temos a satisfação de confirmar o recebimento de sua informação sobre as condições de escuta de nossas emissões em português do dia $15 / 10 / 10$ das $22: 25$ às $22: 45$, [Whora UTC [ ] hora local, pelas ondas de 31 metros, $9410 \mathrm{Khz}$.

Receberemos com muito prazer novas informações sobre a programação.

Departamento de Português Rádio Internacional da China

cripor@cri.com.cn

http://portuguese.cri.cn

$$
\text { Vila zeng }
$$

Fonte:QSL de uma série de seis cartões, dedicados ao uso do bronze na China antiga - acervo do pesquisador 
Dessa forma, pode-se inferir que as imagens acima (Figuras 1 e 2) nos ajudam a compreender que a Rádio Internacional da China (CRI) confirmou a sintonia de 20 minutos da sua programação, captada pelo ouvinte brasileiro, em 15/10/10 na frequência de $9.410 \mathrm{kHz}$. Ao mesmo tempo ainda é possível identificar no QSL a importância do uso do bronze na China antiga para a fabricação de adornos, artefatos ritualísticos e de uso doméstico.

Sendo uma imagem que surge a partir do rádio e se ancora nas pautas de sua programação, nosso conceito do QSL assume sua caracterização como material "radiográfico". "Gráfico", pois é produzido a partir das teorias gráficas; o prefixo "radio" vem de suas origens na palavra rádio e atende a uma especificidade do rádio de suas imagens radiofônicas por fim visualmente materializadas numa linguagem gráfica (SILVA NETO, 2011).

Cada emissora desenvolve sua configuração gráfica, estética e temática na produção de seus cartões. Em geral os QSLs possuem na sua face de frente um desenho gráfico, enquanto o verso é destinado às informações do emissor e receptor: nome da emissora que o produziu, as informações acerca do radioescuta que ouviu a programação, a data, hora e frequência em que ele empreendeu a escuta, bem como a assinatura do diretor da emissora ou agradecimentos pela sintonia do ouvinte (Cf. Figuras 1 e 2).

\section{AS IMAGENS RADIOGRÁFICAS DA GUERRA FRIA}

Ao citar o episódio "A guerra dos mundos" - que gerou um pânico generalizado entre os ouvintes quando estava sendo veiculado no rádio teatro de uma emissora americana - Bordenave (1995) conclui que a comunicação humana não se constitui num fenômeno linear. Para ele todo processo de comunicação está sobrecarregado de símbolos e signos, que permite aos receptores recriar suas mensagens e dar a elas novos significados, que vão muito além da intensão de quem produz e veicula a informação.

Sob esse mesmo efeito, as mensagens do rádio tiveram um curso bem distinto do que propunha os esforços da Guerra Fria. A diversidade de informações contribuiu para a comparação dos fatos e também ampliou novas consciências. Com isso, a radiodifusão internacional também passa a assumir uma nova proposta cultural, tendo o homem, suas crenças, criações e necessidades como motes das pautas radiofônicas e radiográficas. $\mathrm{E}$ a partir desse escopo é possível caracterizar as mensagens do rádio em informações de "atualidades", "opinião" e "entretenimento".

162 Número temático: Desenho e Educação: Cultura Visual e Cidade. A Cor das Letras - UEFS, $n$. 


\subsection{Atualidades}

A informação cotidiana se constitui num dos interesses do rádio internacional e pode ser caracterizada como "atualidades", devido à veiculação dos acontecimentos de impacto imediato. Mesmo que sejam ancorados em fatos históricos, essas informações possuem uma importância pontual do momento presente.

Clausse (apud XIFRA-HERAS, 2011) define esse tipo de informação como: "[...] 'a relação pura e simples, mais ou menos circunstanciada, de um fato - situação, ação, pensamento, opinião - que pertence ao presente mais imediato'". As notícias do cotidiano se reportam aos fatos recentes, de repercussão imediata, mas possuem ligações no passado, pois se deslocam para o futuro com o objetivo de formar comportamentos e opiniões visando uma melhor compreensão do mundo.

Nesse sentido a "atualidade" assume seu lugar na programação, no conjunto das circunstâncias relativas ao cotidiano na sua praticidade e à divulgação do país de emissão. Sob esse olhar, a atualidade se constitui no ato de informar à audiência uma gama de aspectos culturais, econômicos, geográficos, biodiversidades, educação, turismo etc. Isto perpassa pelo conjunto de símbolos, que atuam na configuração da imagem e infraestrutura dos países que as emissoras se encarregam de transmitir ao público estrangeiro.

Geralmente, os serviços internacionais se preocupam em veicular essas informações através de um bloco de notícias que vai ao ar no início das transmissões. No decorrer da programação surgem temas da atualidade, resenhas e reportagens que contemplam essas discussões e resgatam importantes marcos da historiografia mundial, ainda alicerçado no pensamento coletivo da atualidade.

Dentre as emissoras, que emitem para o Brasil e América Latina, destacam-se como exemplo desse ideário coletivo as Figuras 3 e 4, respectivamente pelos cartões da RDPI - Rádio Portugal e Rádio Voz da Rússia. No âmbito radiográfico essas imagens não privam a identidade cultural do país e suas experiências pela conquista do novo mundo. 
Figuras 3 e 4 - QSLs da RDPI — Rádio Portugal e Rádio Voz da Rússia
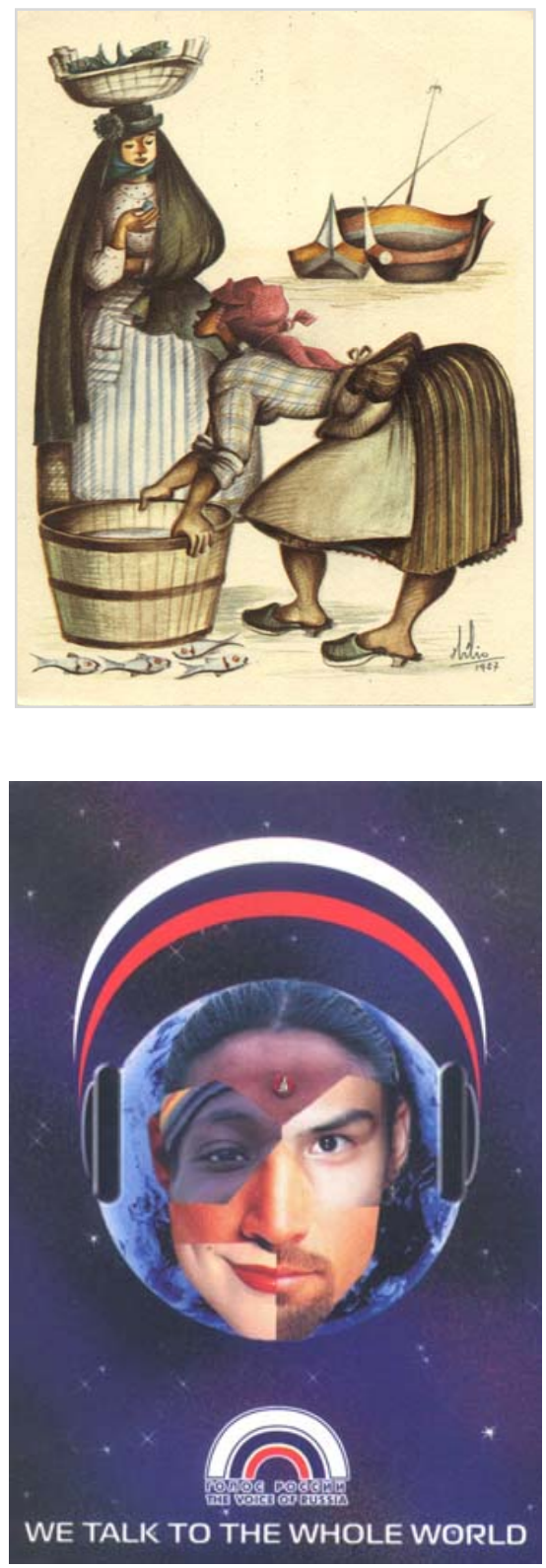

Fonte: Acervo do pesquisador

164 Número temático: Desenho e Educação: Cultura Visual e Cidade. A Cor das Letras - UEFS, n. 13, 2012 
Durante a corrida colonial, Portugal se tornou referência em navegações. Tendo o mare magnum como cenário de fundo o QSL (Figura 3) resgata um fato cotidiano, que Burke (2004) conceitua como a imagem do "instantâneo". O QSL, datado de 1977, retrata, a partir de uma pintura de Abílio Leal, as mulheres portuguesas nos seus afazeres de pescaria e abastecimento de água numa aldeia de pescadores em Nazaré.

O domínio de Portugal sobre os oceanos se traduz num símbolo recorrente desde o período das navegações. Ainda hoje está presente no imaginário social, nas manifestações artísticas e em outras faces radiográficas da emissora portuguesa.

No QSL da Rádio Voz da Rússia (Figura 4) as cores de fundo, em tom de azul-escuro, sugere um campo espacial com vários corpos celestes; e no primeiro plano uma montagem de imagens compõe o assunto principal. Está visualizado um rosto humano formado por vários recortes étnicoculturais, a imagem de um globo terrestre visto de cima, um fone de ouvido e as cores da bandeira russa.

Desde a época da Guerra Fria a antiga União Soviética disputou o espaço sideral com os Estados Unidos. Pontuado pelo desenvolvimento tecnológico e as experiências em vôos tripulados, os soviéticos se anteciparam nas corridas espaciais e conquistaram um feito histórico com o astronauta luri Gagarin - o primeiro homem a atingir a órbita da terra.

São essas experiências coletivas que a Voz da Rússia retoma no desenho do QSL. Um rosto humano formado por recortes e cores evidencia as várias etnias (orientais e ocidentais) na composição da sociedade russa. 0 globo simboliza a Rússia ainda como o centro do mundo e do espaço. As cores da bandeira numa espécie de arco dão formas a um capacete de astronauta. Já o fone de ouvido é uma referência à comunicação de um país em sintonia com o mundo através do rádio. $O$ iconotexto em letras garrafais conclui sua mensagem: "Nós falamos para o mundo inteiro".

\subsection{0 jornalismo de opinião}

O emprego do termo "opinião", sempre remete às compreensões acerca da opinião pública ou formação de pontos de vistas e comportamentos. No seu campo normativo o conceito de opinião recai para um conjunto de circunstâncias e complexidades, que não se esgota em simples interpretações.

Segundo Freitas (2011) o uso da opinião pública vem sendo deslocado ao longo da história, com o advento da imprensa e dos mass media. A 
autora ainda cita Monique Augras em suas ideias sobre o assunto, que perpassam pela compreensão de: "[...] um fenômeno social. Existe apenas em relação a um grupo, é um dos modos de expressão desse grupo e difundese utilizando as redes de comunicação do grupo".

Então, a opinião pública se constitui na própria cultura e se vale desse campo operacional para se autoafirmar como um valor a ser difundido e apreciado pela sociedade. No âmbito do rádio, torna-se visível as intenções ideológicas da Guerra Fria, entre os países alinhados aos blocos mundiais; seja na difusão de uma nova consciência pelas emissoras humanitárias, religiosas e destinadas à proteção da vida, do meio ambiente etc.

As notícias de opinião foram marcantes na emissora americana Voz da América e na soviética Rádio Central de Moscou. Mas, em se tratando da extensão socialista a propaganda sobre o uso do aparato militar, visando combater a expansão capitalista, parece ser mais evidente.

Figura 5 - As imagens da Revolução Chinesa na Rádio Pequim

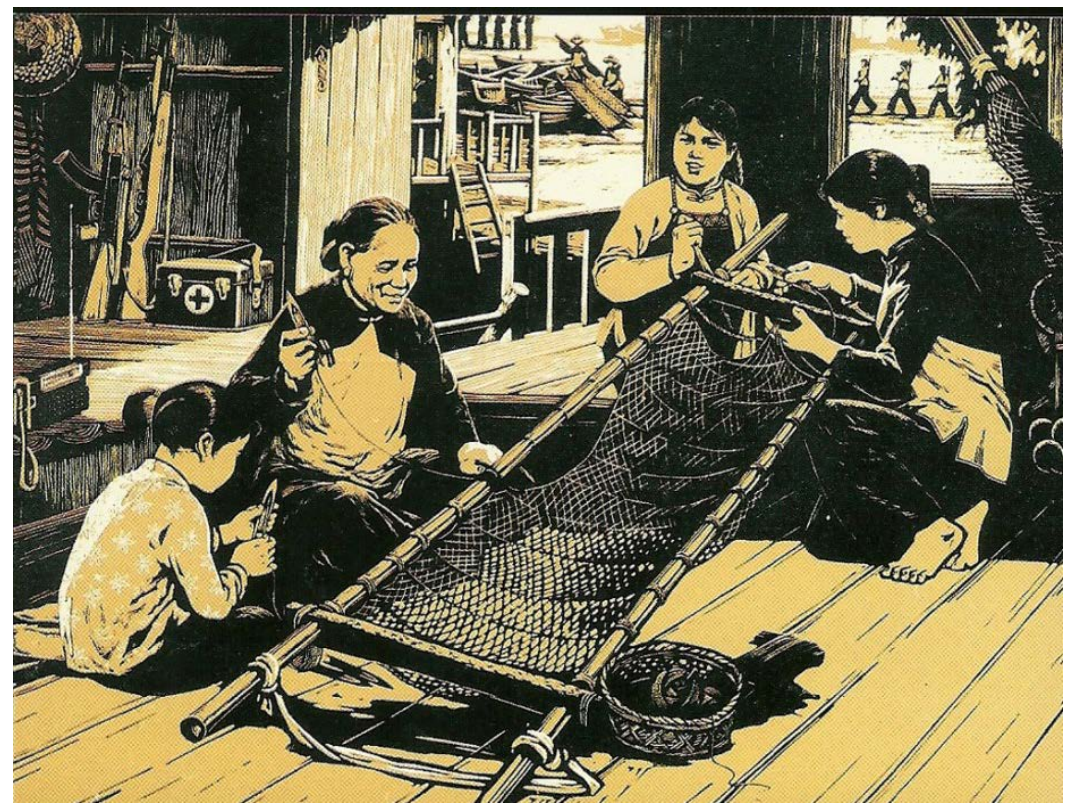

Fonte: QSL ilustrado num Calendário de parede, outubro 2006, do RheinMain-Radio-Clube (RMRC). Frankfurt, Alemanha. QSL da Rádio Pequim, datado de 1974 
Burke (2004) comenta que as imagens produzidas em países socialistas tendem revelar as formas de representação cultural vigente. Sendo assim, os QSLs da Rádio Pequim (Rádio Internacional da China) trazem em seu escopo as imagens que retratam a China nesses contextos históricoculturais. No QSL (Figura 5), emitido em 1974, essa leitura se constitui numa imagem rica em signos e símbolos que permitem uma compreensão histórica e a elucidação dos objetivos pelo qual ela foi produzida.

Seguindo a análise pré-iconográfica, preconizada por Panofsky (1976), é possível identificar que o mote dessa imagem se configura a partir das tarefas artesanais e militares desenvolvidas pelas mulheres chinesas de várias idades, numa aldeia miliciana. $\mathrm{O}$ artefato tecido por elas se assemeIha a uma "maca" e isso fica claro quando se visualiza (na posição superior do QSL) pessoas em posição de guerra. Os demais objetos que estão no cenário também são enigmáticos: um rádio com antena levantada, armas, caixa de primeiro socorro e soldados armados marchando em fila.

Embora a década de 70 começa a desenhar um plano de paz e aproximação da China no eixo ocidental, o país se mantém cauteloso face à instabilidade mundial e prepara seu povo para um iminente embate militar. Nesse desenho do cotidiano, o imaginário e as experiências da guerra parecem ganhar visibilidade na esfera popular feminina.

O "rádio com a antena levantada" denota a ideia de "rádio ligado". Reforça a importância da mídia radiofônica na consolidação do Estado chinês e no seu contato com o mundo. Na sintonia chinesa o rádio serviu para formar mentalidades, noticiar e dar visibilidade à imagem de China no âmbito mundial, bem como na integração da população nacional à desenvoltura dos seus projetos políticos.

Da mesma forma que a Guerra Fria ganhou ênfase nas locuções e imagens radiofônicas, a queda do comunismo e a dissolução das repúblicas soviéticas também tiveram o mesmo destaque. Muito embora o desgaste comunista tenha se repercutido como um efeito dominó pelo Leste Europeu, e se espalhado pelo resto do mundo, a queda do Muro de Berlim parece ser o fato mais contudente desse processo.

Nessa perspectiva o QSL da Rádio Deutsche Welle - Alemanha (Figura 6), retoma uma imagem de uma profundidade histórica e simbólica para os ouvintes. Há nela um forte apelo intrinseco aos arquétipos coletivos, tal como menciona Jean Chevalier sobre o significado da porta no imaginário humano: 
A porta simboliza o local de passagem entre dois estados, entre dois mundos, entre o conhecido e o desconhecido, a luz e as trevas, o tesouro e a pobreza extrema. A porta se abre sobre um mistério. Mas ela tem um valor dinâmico, psicológico; pois não somente indica uma passagem, mas convida a atravessá-la. É um convite à viagem rumo a um além... (CHEVALIER,1990, p. 734-735).

Figura 6 - Portal de abertura política entre as Alemanhas

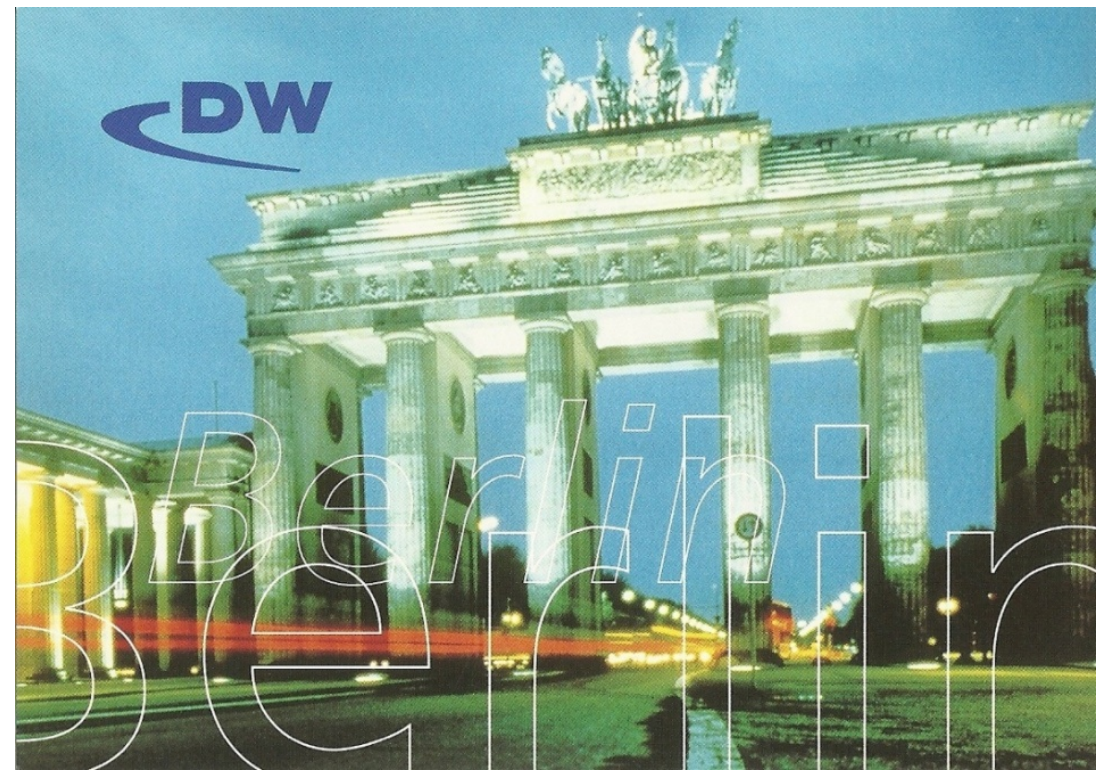

Fonte: Acervo do pesquisador (QSL confirmando a sintonia de 27/10/01, 20:05 UTC, $17595 \mathrm{kHz})$.

A abertura do "Portão de Brandenburgo" se constitui numa das imagens mais marcantes e emblemáticas desse período histórico. Uma porta aberta simboliza a receptividade, um lugar de passagem e transição. Representa a abertura política não apenas entre as Alemanhas, mas para esboçar a imagem de um novo mundo então desgastado pelo jogo ideológico protagonizado entre comunismo $\mathrm{x}$ capitalismo.

\subsection{Entretenimento}

Em sua pesquisa Silva Neto (2005) constatou que a audiência internacional possui outras motivações, que vão além do sentido convencional de ouvir as notícias: o prazer de ouvir rádio, colecionar cartões QSLS, parti- 
cipar das atividades da programação, escrever para as emissoras, receber materiais de divulgação, apreciar esportes, músicas etc.

A sintonia radiofônica se transforma numa distensão da vida cotidiana, pela busca do prazer e da diversão, em consonância com as trocas culturais. Isto é, a estimulação da sensibilidade humana para o entretenimento e apreço cultural em suas esferas artísticas, espirituais e esportivas de vários países pelo viés da ludicidade.

Figura 7 e 8 - A cultura esportiva e tradicional nos QSLs da Alemanha e Albânia ${ }^{6}$

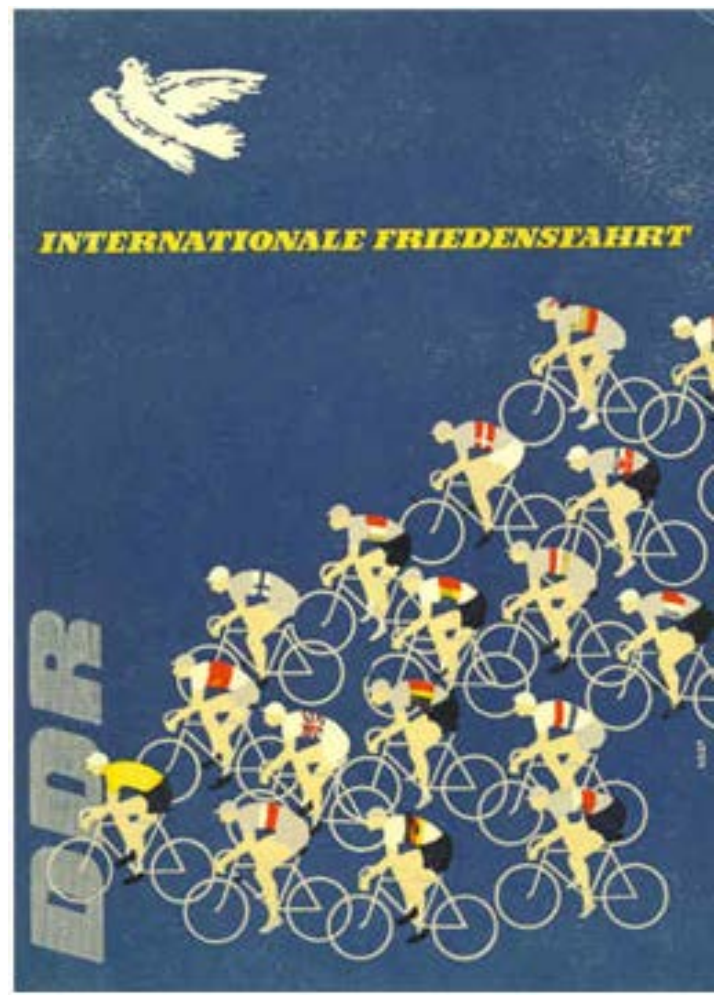

Nesse campo ideológico, a dissiminação de esportes pelo rádio reforça a propaganda dos investimentos no potencial humano, tendo em vista

6 Nota dos editores: o título do QSL em português equivale: corrida internacional da paz; a sigla DDR (por extenso: Deustche Demokratische Republick) designava a República Democrática Alemã, também comumente mais chamada de Alemanha Oriental. 
também sua utilização para empreender o melhor modelo político. Tal como se observa na cena de um campeonato mundial de ciclismo no QSL da Rádio Berlim Internacional (Figura 7). A radiografia esportiva reforça não apenas o desmpenho dos atletas, mas o patriotismo, a qualidade de vida e o potencial possivelmente a ser utilizado como força militar.

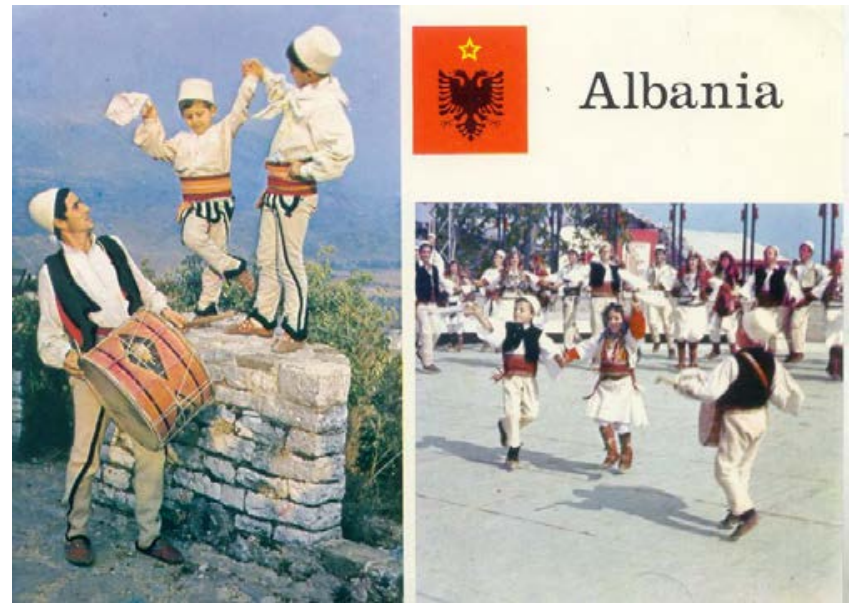

Fonte: Acervo do pesquisador.

Concorda-se com Huizinga (2008), que o lúdico está presente na vida humana sob a forma do jogo e dela participa visando a ampliação cultural. O jogo não consiste apenas no próprio ato de jogar, mas se estende às "necessidades imediatas da vida", na multiplicação de suas imagens e símbolos, portadores da intencionalidade cultural. As mensagens da Guerra Fria, pelo rádio, se alicerçam simbolicamente nas intensões do jogo. E não se trata de um confronto direto, mas num conjunto de estratégias e ações coletivas, que denota a ideia de vencidos e vencedores.

Não obstante ao caráter severo do comunismo, a representação das culturas tradicionais sobressairam com maior relevância nesse conflito ideológico. O Leste Europeu é rico nessas imagens e isso pode ser visualizado nas festas ciganas retratadas no QSL da comunista Rádio Tirana Albânia (Figura 8). Outras imagens semelhantes a essas também ilustram os QSLs da maioria dos países irradiados. Tais manifestações representa a identidade cultural dos povos. Estão ancoradas nos arquétipos coletivos e se constituem nas referências do lúdico, quando praticada sob: "[...] forma de

170 Número temático: Desenho e Educação: Cultura Visual e Cidade. A Cor das Letras - UEFS, n. 
festa, isto é, dentro de um espírito de alegria e liberdade" (HUIZINGA, 2008, p. 14).

O rádio torna-se uma extensão humana e o caráter lúdico extrapola a sintonia. Em suas ondas é possível se deslocar pelo mundo afora e desfrutar de um universo polifônico e multicultural, que se urde nas imagens radiográficas.

\section{CONCLUSÃO}

No percurso deste artigo, procurei situar a radiodifusão internacional como propulsora de imagens sonoras e radiográficas no escopo da Guerra Fria. Tentei demonstrar que esse sistema de comunicação - ainda hoje presente na faixa das Ondas Curtas - tornou-se um fenômeno importantíssimo na difusão de ideologias e informações culturais, que nos ajuda a compreender o mundo e as manifestações humanas.

Isso se dá à medida que a radiodifusão está sedimentada em símbolos sonoro/visuais e se utiliza desses preceitos para retratar e difundir aspectos culturais, turísticos e ideológicos dos respectivos países de transmissão. Evidentemente, essas imagens adqurem sentido porque perpassa pela percepção e apropriação humana, em suas recorrências coletivas.

A partir dessa análise iconográfica, é possível perceber que as imagens radiográficas se constituem num valioso instrumento de propaganda política e mediação cultural. Além de possibilitar a reflexão de fatos históricos, e, por sua vez, circunscritos no imaginário coletivo, também contribui para dar visibilidade aos diferentes pensamentos mundiais, que foram veiculados nos microfones das rádios estrangeiras no ápice da Guerra Fria.

\section{REFERÊNCIAS}

AZEVEDO, Adalberto Marques de. O que é QSL. Atividade DX. DXCB: São Carlos São Paulo,. ano 22, n. 241, out. 2004.

BACHELARD, Gaston. $O$ direito de sonhar. Trad. José Américo M. Pessanha et al. São Paulo: DIFEL, 1985.

BORDENAVE, Juan E. Díaz. Além dos meios e mensagens. Petrópolis: Vozes, 1995.

BURKE, Peter. Testemunha ocular: história e imagem. Bauru: EDUSC, 2004.

CHEVALIER, Jean. Dicionário de símbolos. 3. ed. Trad. Vera da Costa e Silva. Rio de Janeiro: José Olympio, 1990.

ENCICLOPÉDIA Mirador Internacional: Radiodifusão. São Paulo: Encyclopedia Britannica do Brasil, 1990, v. 17. 
FREITAS, Gomes Sdinéia. Formação e desenvolvimento da opinião pública. Disponível em: <http://www.portal-rp.com.br/bibliotecavirtual/opiniaopublica/0017.htm>. Acesso em: 16 maio 2011.

HUIZINGA, Johan. Homo ludens: o jogo como elemento da cultura. Trad. João Paulo Monteiro. São Paulo: Perspectiva, 2008.

JOLY, Martine. Introdução à análise da imagem. Trad. Marina Appenzeller. Campinas: Papirus, 1996.

MCLUHAN, Marshall. Os meios de comunicação como extensões do homem. 4. ed. São Paulo: Cultrix, 1964.

PANOFSKY, Erwin. Significado nas artes visuais. São Paulo: Perspectiva, 1976.

RADIO DEUTSCHE WELLE. In: Alô amigos. Editorial. Colônia/Alemanha, 1992.

SERVIÇO BRASILEIRO DA BBC. O Rádio no Brasil. História do Serviço Brasileiro da BBC. Londres - Inglaterra: British Broadcasting Corporation, 1998. 5. CD da série.

SILVA NETO, Antonio Argolo. Pedagogia das ondas curtas: a influência das rádios internacionais na educação dos ouvintes brasileiros. 2011. 157 f. Monografia de Graduação. Universidade Estadual do Sudoeste da Bahia, Jequié/BA, 2004.

SILVA NETO, Antonio Argolo. Radiodifusão internacional: o desenho do mundo na sintonia das ondas curtas. 2011. 206 f. Dissertação de Mestrado. Universidade Estadual de Feira de Santana, Feira de Santana/BA, 2011.

XIFRA-HERAS, Jorge. Teorias e conceitos: a informação cotidiana. Disponível em: $<$ http://www.portal-rp.com.br/bibliotecavirtual/relacoespublicas/teoriaseconceitos/0014. htm>. Acesso em: 22 maio 2011. 